\title{
Market-Driven Management: A Critical Literature Review
}

\author{
Niccolò Gordini*
}

\begin{abstract}
In global markets the firms adopt a market-driven approach characterized by a careful monitoring of the competition and by the development of high skills in understanding the market and its stakeholders, in order to choose the most suitable competitive strategy. The paper provides a critical review of the main literature on market-driven management, analysing its evolution from Japan to the USA and Europe.
\end{abstract}

Keywords: Market-Driven Management; Market Orientation; Literature Review

\section{From Product Orientation to Marketing Management}

Until the 1950s, with demand exceeding supply (scarcity of supply), management models paid tribute to the scientific management (Taylor 1911; Ford 1922, 1926, 1930) model introduced by Ford in the 1930s. The Ford model, which was based on the idea of giving every citizen a car at an acceptable price, led to the introduction and spread of mass production in the United States. This model was perfect for the market conditions in the United States in the Twenties. The then Chairman of General Motors, Albert P. Sloan (1990), described these conditions pinpointing a radical transformation, between 1924 and 1926, that changed the automotive market from the production of a very few, very expensive units for a small number of customers, to the era of the good quality car for everyone. The Ford approach, which was based on the supremacy of product orientation and the theory of the scientific organisation of labour, was designed to achieve economies of scale based on standardised mass production, the rationalisation of the manufacturing process and a reduction in dead time, by the introduction of the assembly line ${ }^{1}$. Ford succeeded in transforming the car from an elite product that was expensive to purchase and to run, into a standardised product for the masses, with a purchase prize that was accessible to a large number of purchasers (symbolised by the Ford Model $\mathrm{T}$ that could be painted any colour so long as it was black). In this business model, which focused on the product and on price competition, the market was still homogeneous and not differentiated. Supply controlled demand, defining the quantities produced and sold, and therefore the prices, and had the knowledge and information necessary to programme future activities. The entire output was sold at the price set by the manufacturer and there were usually no stocks $^{2}$ of finished products because everything produced was sold. But this situation

\footnotetext{
*Assistant Professor of Management, University of Milan-Bicocca (niccolo.gordini@ unimib.it)
}

Edited by: ISTEI - University of Milan-Bicocca

ISSN: 1593-0319

Gordini Niccolò, Market-Driven Management: A Critical Literature Review, Symphonya. Emerging Issues in Management (symphonya.unimib.it.), n. 2, 2010, pp. 95-107

http://dx.doi.org/10.4468/2010.2.08gordini 
was not only the effect of the presence of a small number of suppliers with respect to demand or of the general lack of alternative choices (scarcity of supply), but rather the result of an attempt to market supply while closely monitoring quantities, in order to meet a demand whose needs and principal characteristics were known.

In the 1950s the US economy entered a period of sustained growth, evolving from a scarcity economy (D>S) to one of demand and supply in dynamic balance, or controlled competition $(\mathrm{D} \approx \mathrm{S})$. According to Chamberlin (1933), who coined the term "product differentiation", Sloan (1990) grasped these changes and, to respond to the saturation of demand, began to highlight the characteristics of his own models, launching increasing differentiated models on the market. In this period a new management philosophy, known as Marketing Management, began to take hold. Unlike Scientific Management, this model presupposes that the company has detailed knowledge of demand and of its segments, so that it can offer differentiated products that are able to fill different market spaces. Companies modify their strategies from price competition to non-price competition. In other words they invest in product differentiation and, therefore, in demand segmentation to increase sales volumes and stabilise market share compared to their competitors, trying to stave off competition based on prices. Unlike scarcity of supply, on markets with demand and supply in dynamic balance (controlled competition) there are numerous alternatives to choose from, all with the same end goal and belonging to the same product class to meet the same need. The presence of alternatives allows demand to express its capacity for choice, highlighting different companies' capacity to react to satisfy numerous demand segments. As a result, with marketing management, the management process starts from demand to define the characteristics of a product that is destined to fill a specific 'supply vacuum', by creating segments that tend to be homogeneous internally and heterogeneous externally, easily identifiable and stable for longer periods of time. The demand segmentation process enables companies to deal with the inhomogeneity they come up against, and to search for homogeneous conditions on which to focus their policies.

Starting in the early 1980s, with the globalisation of markets and the saturation of segments, further changes occurred in market conditions; these led Ohno, the father of the Toyota Production System and of market-driven management, to ask himself how to compete in increasingly dynamic and global markets.

\section{Ohno and Ohmae: the Japanese School of Management}

Taiichi Ohno, following the philosophy of Deming (1982), is universally recognised as the father of the Toyota Production System and, by extension, of the manufacturing philosophy known as 'lean manufacturing' (based on the 'integrated plant', the 'just-in-time' system and 'total quality') which has generated the modern management philosophy known as market-driven management. The Toyota System has numerous similarities with previous manufacturing models, implementing some of their distinctive features in full. However, underlining some of the main differences helps to establish the extent to which this system is an element of discontinuity in relation to scientific management and to marketing management, and the basis for the development of market-driven management.

The first, fundamental element of discontinuity regards the market conditions in which these corporate policies are successful. The Toyota model was created and developed in a competitive environment which differs significantly from both the 
Ford model (born in a market where supply was scarce and based on the idea of the absence of limits - the infinite expandability of the demand framework) and from marketing management, which was based on controlled competition and on the importance of controlling demand by differentiating supply through non-price competition logics. The market of the late 1970s was no longer stable and steady, in a limited, easily identifiable space with defined physical and/or administrative boundaries. It was dominated by the oil crisis, by saturated demand, by the competitive role of time (time-based competition) and space (market-space competition), by the struggle between giant manufacturing concerns on increasingly dynamic, extended, competitive, demanding and selective markets. The Toyota system developed in a 'finite' market, characterised by awareness of the 'limit', of the impossibility of continuing to produce ever greater quantities of undifferentiated products and of the need to produce smaller quantities of increasingly differentiated products to face up to a demanding and saturated market. In these stagnant conditions, companies have to cut costs without increasing the manufacturing scale, in fact reducing and differentiating it.

These considerations lead us to the second element of discontinuity: the relationship between company and market. The Toyota model entails a clear inversion in this relationship: from a situation of 'supply-demand-competition', where supply 'dominates' demand thanks to low competitive intensity, to a situation of 'competition-demand-supply'. It is no longer the company that 'creates' the market, as it was in the Ford model, because of the scarcity of supply, but competitors and the voluble preferences of the market that determine the structure and manufacturing decisions. Supply no longer influences the market by defining the quantities to produce on the basis of demand that changes slowly and steadily. In a situation of oversupply, competitor's manufacturing decision and the subsequent volubility of demand constantly modify output, determining its programming. The Toyota system encourages output to meet the market halfway by producing small quantities of a large number of models, unlike the American market that produced large quantities of a small number of models. This clear inversion of the supplydemand relationship emerges clearly if we analyse market information flow trends. In scientific management and marketing management the information flow moves in a linear fashion from top to bottom, originating from company management, which takes the decisions regarding the manufacturing volumes and manufacturing times of each department, and then extends to all the components of the cycle until it reaches the market in a 'supply-demand' relationship. In the Toyota system, on the other hand, communication goes from bottom to top. Company management is still responsible for defining strategies, but the information flows, particularly those of an operational nature, originate from the market and are transmitted retroactively to the working cycle, by the 'kanban' technique.

Globalisation and the new competitive conditions it generates led Kenichi Ohmae (1982, 1986, 1990, 1992, 1994, 1999, 2001, 2005) to support and corroborate Ohno's theories. In 'The Borderless World' published in 1990, Ohmae predicted the rise and success of globalisation, coining the very word. In his studies, he synthesises today's emerging trends into the first coherent view of tomorrow's global economy and its implications for politics, business and personal success. For Ohmae, globalisation is not a myth, but a fact. We cannot stop it. It has already happened and we are moving into a new global stage. According to Ohmae's theory, a radically new world is taking shape from the ashes of yesterday's nation- 
based economic world. To succeed, companies must act on the global stage, leveraging radically new drivers of economic power and growth. The interconnected, interactive and global economy challenges both the way we see business and the way we do it.

As a result, globalisation, the elimination of space-time competition limits and the growth of oversupplied markets force companies to adopt new management policies that are market-oriented (market-driven management) and no longer limited to the product (scientific management) or to demand (marketing management). As the company's control over the market is reduced it also loses the possibility of adopting a long-term strategic plan based on certain, regular deadlines, and must learn to observe the market and to operate with very short action/reaction times and extended spaces that can no longer be identified with specific physical/administrative/cultural contexts. And it is in this competitive situation that market-driven management establishes itself.

\section{From the Japanese School to the American School: Market-Driven Management}

Market-driven management began to establish itself in the late 1980s as an effect of market globalisation and the many innovations introduced by Japanese scholars and by Toyota (flexible production, lean production, just in time, total quality, mass customisation), who were the first to underline the importance of corporate management focused on the market and on competition rather than on demand (marketing management) or the product (scientific management).

However, it was thanks to the work of a group of American scholars (Best 2009; Day 1990, 1994, 1998, 1999; Narver and Slater 1990; Slater and Narver 1994, 1998, 1999; Jaworski, Kohli and Sahay 2000; Webster Jr. 1988, 1992) that this strongly market-oriented management model began to spread in the West. These scholars have refined the concept of market-driven management, valid measures of the market orientation developed, and a strong relationship demonstrated between market orientation and business performance (Jaworski and Kohli 1993, 1996; Narver and Slater 1990; Slater and Narver 1994, 1999). All these studies support the conclusion that market orientation is essential to success in a global market. However, according to Slater and Narver (1999), much that has been written about the nature and consequences of being market oriented is incomplete or incorrect. This misundertanding has occurred because authors, without realizing it, are often confusing two different concepts: marketing orientation and market orientation. In fact, marketing-oriented and market-oriented are occasionally used synonymously (Shapiro 1988), but there is actually a profound difference between them, which marks the evolution from marketing management to market-driven management.

On one hand, the concept of marketing orientation is closer to the traditional marketing concept popularised by the US Business Schools (McCarthy 1960; McNamara 1972; Kotler 1967, 2005) and in particular to its role as a corporate function that coordinates and manages the four Ps in order to make a company more aware of its customers' needs (Lambin 2000, 2007, 2008).

The concept of market orientation (Lambin 1998, 2005; Webster Jr. 1988; McGee and Shapiro 1988; Day 1990, 1994, 1998, 1999), on the other hand, is a substitute to the traditional marketing concept of the four Ps. This is more than just a semantic issue. This concept rethinks the role of the marketing function and 
extends the definition of market not only to the customer, but to all its main players (Lambin 2000, 2007, 2008). The traditional marketing orientation concept tends to be more short-term oriented and mainly concerned with the functional role of marketing in co-ordinating and managing the four Ps to promote the firm's offerings. The market orientation concept, by contrast, a) enlarges the market definition not only to the customers, but also to the online market actors, distributors, competitors, influencers, suppliers, retailers, baks and other stakeholders; b) claims that creating customer value is the only way for a firm to achieve its objective of profit and growth, thereby, creating shareholder value; c) states that enhancing customer value is the responsibility of everyone in the organisation; d) de-emphasises the functional roles of marketing departments (Lambin 2007, 2008). The development of a market orientation concept, therefore, cannot be left entirely to the marketing department because it demands the involvement of all company functions (Day 2000/2001). These changes are motivated by the increased complexity of the competitive environment which becomes global, deregulated and deeply modified by the information technology revolution (Lambin, 2007, 2008). Based on the aforementioned considerations, the concept of marketing that is taking hold in over-supplied global markets is radically different from that of other competitive conditions.

Until the 1950s, in scarcity economics, marketing was not a formalised function inside a business. The sales department pursued the sole goal of selling the product. Product planning, distribution, pricing and sales were seen as separate activities and an overall corporate policy that synergetically combined all these elements and strategically analysed the links between them did not exist yet.

Starting in the 1950s, as competition began to be more intense, the concept of marketing began to take hold, marking the evolution from a focus on sales to a focus on the customer. In this regard Drucker (1954) maintained that 'marketing represents such an important function for the company that it is no longer possible to limit it and identify it only with a strong sales department. Marketing is not only a much vaster concept than that of sales, but it is not even a specialist activity, an autonomous corporate function that is separate from all the others, regarding and influencing all corporate activities, observed from the viewpoint of the end result, i.e. from the customer's viewpoint.' In an article of 1960, to underline the importance of this change, Keith compared the evolution from a focus on sales to a focus on the customer to the Copernican revolution: it is the company that revolves around the customer rather than the customer around the company. Customeroriented marketing underpins the development of an organisational culture and a shared sum of values that is recognised inside the company to place the consumer at the centre of company strategies and policies. Each component of the organisation must think of how his own work can produce value for the consumer. As McNamara noted (1972), the concept of marketing is 'a philosophy of business management based on a company-wide acceptance of the need for customer orientation, profit orientation and recognition of the important role of marketing in communicating the needs of the market to all the major corporate departments'. Thus, marketing-oriented companies focus on understanding the expressed desires of the customers and on developing products and services that satisfy those desires (Slater and Narver 1998, 1999). The problem with this philosopy is that it is concerned with satisfying customer's expressed needs, it is reactive and short term in focus, it generally leads to adaptive rather than generative learning (Senge 1990) and it leads to internal conflict over resources allocations and business priorities. 
Finally, from the 1980s, the emergence of new market paradigms on the heels of spreading globalisation, caused the concept of marketing to evolve further, from marketing management to market-driven management (Webster Jr., 1994). On global, fiercely competitive markets, marketing management may pose significant problems in terms of implementation, including: difficulty in attributing true priority to competition; marketing expenditure that is gradually less efficient; the creation of a marketing bureaucracy. These problems, combined with the spread of new competitive conditions, have been the main causes of the spread of marketdriven management. Narver and Slater (1990) suggested that market-driven companies consist of three behavioral components (customer orientation, competitor orientation, and interfuctional coordination) and two decision criteria (long term focus and profitability). Thus, compared to marketing oriented companies, market-driven companies scan the market more broadly, have a longerterm focus, and are much more likely to be generative learners (Senge 1990). Morevoer, market-driven companies seek to understand customer's expressed and latent needs, and the capabilities and plans of their competitors through the processes of acquiring and evaluating market information in a systematic and anticipatory manner. Jaworski, Kohli and Sahay (2000) point out that reacting to customers' expressed needs is usually inadequate for the creation of competitive advantage. Market-oriented companies do not ignore the expressed needs of their customers, but they realize that, since competitive advantage is often temporary, the firm must understand how customers' needs are evolving and develop innovative solutions to those needs. Thus, the greater the market orientation of the firm, the greatert the proportion of its activities that are oriented to understanding latent needs (Slater and Narver 1998, 1999).

One of the most important contributions to the development of this management policy came from George Day (1999, 2000/2001), who defined the market-driven company as a company with superior skills in understanding, attracting and keeping valuable customers. Day (2000/2001) also clarified that this is not a definition based on absolute standards which, if respected, always qualify a successful market-oriented company, but that these criteria vary according to the competitive alternative which the company is dealing with. The concept of 'superior' highlights this 'relativity', underlining that being successful in a competitive market means performing better than the competition or a specific competitor. Although there are no rules or behaviour than can guarantee that all companies will be successful market-driven companies, Day (2000/2001) identifies three characteristics which, when skilfully combined, i.e. a combination that is superior to that of the competition, may produce a successful market-driven company. These characteristics may be summed up as:

- a culture focused on the outside world, with dominant convictions, values and behaviour that highlight the importance of creating value for the customer and of the continuous search for new sources of competitive advantage;

- particular distinctive capabilities to perceive the market, to relate to market demand, and to define anticipatory strategies. This means that market-driven companies understand their markets in greater depth and are more skilful in forging close links with more important customers. The clarity of their strategic ideas helps market-driven organisations to adopt winning lines of 
conduct that anticipate opportunities rather than reacting to threats from the market;

- an organisational configuration that enables the whole company to constantly anticipate customers' changing needs and to respond to market conditions. This configuration includes all the other capabilities to generate value for the customer: from product design to order filling, as well as an adaptive organisational structure and all the systems to support, control, assess and develop human resources. All the elements of the organisational configuration are aligned with a superior value proposition.

These three elements represent a shared base of knowledge with which a marketdriven company collects and disseminates its information and its own view of the market. This knowledge underpins relations with customers, inspires the corporate strategy and focuses employees' attention on the needs of the market.

According to Best (2009) an orientation to the market is not achieved by a simple statement of intent, but presupposes a market-driven management philosophy, which demands: the reorganisation of the company around the market rather than around the product or plants; a corporate culture driven by results that monitors varying demand and instability in the competitive environment; the preparation of new metrics of intangible and tangible factors, to assess the corporate performance in changing external contexts.

\section{Market-Driven Management and the Evolution of Market Orientation: the European School}

Lambin was the first in Europe to propose a change from customer orientation to market orientation, in 1998. He identified four stages that characterise the evolution of the concept of marketing:

- passive marketing (orientation to product);

- operational marketing (dimension of action and orientation to sales);

- strategic marketing (dimension of analysis and orientation to customer);

- market-driven management (cultural dimension and orientation to market).

In Lambin's subsequent studies $(2000,2007,2008)$, the competitive orientation to global markets was developed further and in concrete terms. The author directed his analysis to the role of market-driven companies and their organisational structure. On global markets, companies are shifting constantly from a customer orientation to a much vaster market orientation in which the market is seen as a complex ecosystem where the cultural dimension is present in the corporate organisational structure. The distinctive feauture of the Lambin's thought remains its focus on the concept of market orientation as a substitute to the traditional marketing concept of the four Ps theorized by the US Business Schools. According to Lambin $(2007,2008)$, it is possible to identify four elements that distinguish the concept of marketing from the concept of market-driven management:

- marketing focuses on the customer, while market-driven management enlarges the market definition not only to the customers, but also to all the players that are present on it (customers, competitors, supplier, retailer, bank, other stakeholders) according to an outside-out logic; 
- marketing is based on a simple 'pull market ${ }^{3}$ ' model (strategic response marketing), while market-driven management is based both on the requests of the market (pull market) and on innovative models linked to a technological impulse (proactive strategic marketing);

- marketing tends to be more short-term oriented and mainly concerned with its functional role in co-ordinating and managing the four Ps to promote the firm's offerings, while market-driven management is oriented to action, analysis and culture;

- the concept of marketing is limited only to the marketing function, while market-driven management is based on a culture that pervades every level and every function of the firm, striving to achieve a complete functional interaction. Developing market relations and enhancing customer value is the responsibility of everyone in the organisation.

It was around this last point that Lambin $(2007,2008)$ formulated his most significant considerations, underlining that the radical changes that had taken place in the competitive environment had redefined the concept of marketing but had also had serious repercussion on the role played by marketing within the corporate organisational structure. Marketing is no longer a distinct, independent corporate function. In a market-driven company, inter-functional coordination is particularly important because it implies the involvement of all levels of the company organisation and not only the marketing operatives. In order to prosper and grow, a company must find a systematic consistency between all its parts, to satisfy the interests of all the parties that gravitate around it, drawing extensively on a shared culture. Bureaucratic, hierarchical and functional organisations, with a low level of interaction, must evolve into more efficient organisms. Companies that operate on global markets must strive towards new organisational forms with a horizontal, transverse division of roles, to replace traditional vertical structures organised by processes. The main advantages of this structural evolution are: a leaner organisational structure and decision-making process; the possibility of developing a simple, efficient and flexible internal organisation (in terms of the rapid, correct transfer of information, controls, etc.); lower costs, particularly for personnel, due to the elimination of functional 'fragmentation' and the resulting proliferation of substantially identical roles and duties ${ }^{4}$; greater interaction between all parts of the organisation. It therefore becomes clear that the key word for market-driven companies that have to deal with the competitiveness of global markets is interaction. It is through the direct interaction of the various decision-makers and operational teams that a strategic global approach make be defined and put in place.

Lambin and his scholars (for example, see Schuiling 2000/2001) are therefore responsible for the most concrete attempt to contextualise market-driven management to European markets. However, his model has two significant limitations. First of all, Lambin underlines the need to go from a vertical structure organised by processes to a transverse structure, but does not show how to achieve it in terms of figures, roles and tasks. He does not consider the fact that, in large global corporations, this evolution demands even greater flexibility and the reduction of superfluous costs, particularly for personnel. A second limit lies in the clear separation between the various concepts of marketing (passive marketing, operational marketing, strategic marketing, market-driven management), as if they were independent. But this distinction, although useful theoretically and as 
historical analysis, is a conceptual rather than a real distinction, independent of the market conditions in which the company operates.

\section{5. 'Before and Better than Competitors': Market-driven Management and Global Competition}

Globalisation, which marks the end of traditional space-time competition limits and the spread of interconnected markets with different levels of competitive intensity, has prompted large corporations to operate in contexts dominated by market-space competition and time-based competition that highlight the achievement of vital cost economies (of purchasing, manufacturing, distribution, communications and sales). Global markets therefore accentuate the adoption of a market-oriented management model by companies. According to Brondoni and the Milan-Bicocca Business School, to whom we owe some of the most concrete attempts to interact with Japanese, American and European scholars, market-driven management is a corporate development strategy oriented to the market (whose goal is to generate instability of supply and to increase the variability of demand) and dominated by competitive customer value, which proposes direct, continuous benchmarking with competitors (before and better than competitors). Market-driven companies must identify a competition space (demand vacuum), choosing the product characteristics that meet the temporary and therefore highly instable expectations of demand (Corniani 2002, 2005). In this type of strategy, product intangible assets (i.e. pre-sale services, after-sales services, logistics, design, branding) play a leading role. They can only be effectively exploited if there is a conscious, modern approach to intangible corporate assets (corporate culture, information system and corporate identity). On global, over-supplied markets in particular, where customers are increasingly voluble and disloyal, market-driven management presupposes: activities that address the markets (i.e. competitors and demand) rather than customer satisfaction alone; market policies based on continuous innovation and competitive pricing to meet changing and instable demand; and finally, new metrics to evaluate the factors (particularly intangible, corporate and supply) that influence corporate performance in the short and very short term. In global contexts companies must therefore adopt a competitive approach to the market which takes the form of careful monitoring of the competition and skill in understanding the market, the operators who work on it, their key characteristics and their products, in order to choose the most suitable course of action, thanks to better and faster understanding of what is being achieved in the extended market space (market-space competition). The market-driven company is therefore one that not only reveals a superior ability to understand, attract and keep valuable customers (Day 2000/2001), but one that is also able to organise and exploit resources and skills in order to act before and better than competitors'. Finally, from an organisational viewpoint, market-driven companies are an innovative element that obliges all corporate functions (manufacturing, sales, marketing, finance, etc.) to operate consistently and synergetically with each other and with the environment, to be aware of competitive conduct, to anticipate the expectations of demand, and to be ready to propose solutions that go beyond the roles of the individual functions and the physical space of natural competition. Market-driven management focuses on an outside-in vision based on the identification of products whose value is higher than those of competitors in order to force the intersection with demand, on the creation of the 
maximum temporary value, offering goods to specific demand bubbles (Corniani 2002, 2005), and on the time-based acquisition of market knowledge. Corporate management is therefore qualified by: a corporate dimension, with specific behavioural standards and values (corporate responsibility) that are consistent with the complexity and transparency of global markets; an analytical dimension based on continuous monitoring of the competition system and in line with modern corporate economics sustained by pull/push corporate communications flows and forced to operate in global markets in a state of instability; and finally, a proactive dimension in which time and space are competitive factors (time-based competition and marketspace management) and no longer given elements that are foreign to corporate reality (Brondoni 2008, 2009; Gnecchi 2009).

The spread of market-driven management in Italy, thanks to the work of the Milan-Bicocca School of Management at the end of the $20^{\text {th }}$ and early $21^{\text {st }}$ centuries, has resulted in ever-growing interest in the analysis of strategic and management issues from a market-driven approach. Several Italian scholars adopted different theoretical approaches to address the link between market-driven management, global markets, corporate governace and entrepreneurship.

Salvioni $(2003,2005,2008)$ examined the models of corporate governance and their most appropriate configuration in market-driven companies. Zucchella and Majocchi (2008), by analysing the link between global entrepreneurship and market-driven enterprise, stated that the outside-in logic typical of market-driven companies, which are striving constantly to fill instable, risky and temporary demand vacuums, goes hand in hand with the proactive, innovative and risk-taking behaviour of the entrepreneur. Sciarelli (2008) on the other hand, examined the possible links between the resource-based view and market-driven management, identifying points of contact in market-driven companies' superior ability to orient the market because they can draw on particular intangible assets at corporate and product level. Other studies (Vallini and Simoni 2009) examined the importance of adopting an extensive market-driven approach, adopted to compete not only on outlet markets (on demand) but also on input markets (on supply). Global markets oblige companies that wish to obtain a lasting, sustainable competitive advantage to be market oriented in their management of all their relationships, whether upstream (input markets) or downstream (outlet markets). As a result, companies will no longer have to operate alone in a competitive context (oversupply, demand and supply in dynamic balance or scarcity of supply), but in one of the possible combinations of the same.

\section{Bibliography}

Best Roger J., Market-Based Management, Prentice Hall, 5th ed., 2009.

Brondoni Silvio M., Market-Driven Management, Competitive Customer Value and Global Networks, Symphonya. Emerging Issues in Management (symphonya.unimib.it), n. 1, 2009. http://dx.doi.org/10.4468/2009.1.02brondoni

Brondoni Silvio M., Overture de Market-Driven Management and Competitive Customer Value, Symphonya. Emerging Issues in Management (symphonya.unimib.it), n. 1, 2009.

http://dx.doi.org/10.4468/2009.1.01ouverture

Brondoni Silvio M., Ouverture de Market-Driven Management and Global Markets - 2, Symphonya. Emerging Issues in Management (symphonya.unimib.it), n. 2, 2008.

http://dx.doi.org/10.4468/2008.2.01ouverture 
Brondoni Silvio M., Ouverture de Market-Driven Management and Global Markets - 1, Symphonya. Emerging Issues in Management (symphonya.unimib.it), n. 1, 2008.

http://dx.doi.org/10.4468/2008.1.01ouverture

Brondoni Silvio M., Market-Driven Management, Competitive Space and Global Networks, Symphonya. Emerging Issues in Management (symphonya.unimib.it), n. 1, 2008. http://dx.doi.org/10.4468/2008.1.02brondoni

Chamberlin Edward H, Theory of Monopolistic Competition, Harvard University Press, Cambridge, MA, 1933.

Corniani Margherita, Demand Bubble Management, Symphonya. Emerging Issues in Management (symphonya.unimib.it), n. 1, 2002.

http://dx.doi.org/10.4468/2002.1.08corniani

Corniani Margherita, Market, Segment and Demand Bubble, Symphonya. Emerging Issues in Management (symphonya.unimib.it), n. 2, 2005.

http://dx.doi.org/10.4468/2005.2.02corniani

Corniani Margherita, Push and Pull Policy in Market-Driven Management, Symphonya. Emerging Issues in Management (symphonya.unimib.it), n. 1, 2008. http://dx.doi.org/10.4468/2008.1.05corniani

Day George S., Creating a Market-Driven Organization, Sloan Management Review, 1999, pp. 11-22.

Day George S., The Capabilities of Market-Driven Organization, Journal of Marketing, vol. 58, n. 4, 1994, pp. 37-52.

http://dx.doi.org/10.2307/1251915

Day George S., What Does It Mean to be Market-Driven?, Business Strategy Review, vol. 9, n. 1, 1998, pp. $1-14$.

http://dx.doi.org/10.1111/1467-8616.00051

Day George S., Market-Driven Strategy: Processes for Creating Value, Free Press, New York, 1990.

Day George S., Market-Driven Winners, Symphonya. Emerging Issues in Management (symphonya.unimib.it), n. 2, 2000-2001. http://dx.doi.org/10.4468/2001.2.02day

Day George S., The Market-Driven Organization, Free Press, New York, NY, 1999.

Deming Edwards W., Quality, Productivity and Competitive Position, Massachusetts Institute of Technology, Center for Advanced Engineering Study, Cambridge, MA, 1982.

Drucker Peter F., The Practice of Management, Harper \& Brothers, New York, NY, 1954.

Ford Henry, Crowther Samuel, My Life and Work, Garden City Publishing Company Inc, New York, NY, 1922.

Ford Henry, Crowther Samuel, Today and Tomorrow, Doubleday, Page \& Company. Co-edition, New York, NY, 1926.

Ford Henry, Crowther Samuel, Moving Forward, Garden City Publishing Company Inc, New York, NY, 1930.

Gnecchi Flavio, Market-Driven Management, Market Space and Value Proposition, Symphonya. Emerging Issues in Management (symphonya.unimib.it), n. 2, 2009. http://dx.doi.org/10.4468/2009.2.04gnecchi

Hitt Michael A., Ireland Duane R., Hoskisson Robert E., Strategic Management. Competitiveness and Globalization, Thomson South Western, Mason, 2005.

Jaworski Bernard, Kohli Ajay, Market Orientation: Antecedents and Consequences, Journal of Marketing, 57, 1993, pp. 53-70.

Jaworski Bernard-Kohli Ajay, Market Orientation: Review, Refinement, and Roadmap, Journal of Market-Focused Management, 12, 1996, pp. 119-163.

Jaworsky Bernard, Kohli Ajay K., Sahay Arvind, Market Driven Versus Driving Markets, Journal of the Academy of Marketing Science, vol. 28, n. 1, 2000, pp. 45-54. doi: 10.1177/0092070300281005

Kotler Philip, Marketing Management, Upper Saddle River, NJ, Prentice-Hall, 1967 e 2005. 
Lambin Jean-Jacques, Ouverture de 'Market-Driven Management and Competitive Customer Value', Symphonya. Emerging Issues in Management (symphonya.unimib.it), n. 2, 2009.

http://dx.doi.org/10.4468/2009.2.01ouverture

Lambin Jean-Jacques, Capitalism and Sustainable Development, Symphonya. Emerging Issues in Management (symphonya.unimib.it), n. 2, 2009 http://dx.doi.org/10.4468/2009.2.02lambin

Lambin Jean-Jacques, Market-Driven Management: Strategic and Operational Marketing (5nd edition), Mc-Graw Hill, 2008.

Lambin Jean-Jacques, Changing Market Relationship in the Internet Age, UCL Presses Universitaries de Louvain, Belgique, 2008.

Lambin Jean-Jacques, Market-Driven Management (2nd edition), Mcamillan, London, 2007.

Lambin Jean-Jacques, Strategic Marketing Revisited After 9/11, Symphonya. Emerging Issues in Management (symphonya.unimib.it), n. 1, 2002.

http://dx.doi.org/10.4468/2002.1.02lambin

Lambin Jean-Jacques, Market-Driven Management: Strategic and Operational Marketing, Macmillan, London, 2000.

Lambin Jean-Jacques, Le Marketing Strategique. Du Marketing à l'Orientation Marché, Ediscience, Paris, 1998.

McCarthy Jerome E., Basic Marketing - A Managerial Approach, Irwin, Illinois, 1960.

McNamara Carlton P., The Present Status of the Marketing Concept, Journal of Marketing, January, 1972, pp. 50-57.

http://dx.doi.org/10.2307/1250868

Narver John C., Slater Stanley F., The Effect of Marketing Orientation on Business Performance, Journal of Marketing, 1990.

http://dx.doi.org/10.2307/1251757

Ohmae Kenichi, The Next Global Stage: Challenges and Opportunities in Our Borderless World, Prentice Hall, Upple Saddle River, New Jersey, 2005.

Ohmae Kenichi, Globalization, Regions and the New Economy, UCLA, Center for Globalization and Policy Research, Working Paper n. 1, January 2001.

Ohmae Kenichi, The Borderless World. Power and Strategy in the Interlinked Economy (revised edition), Harper Collins Publisher, New York, NY, 1999.

Ohmae Kenichi, The Borderless World. Power and Strategy in the Global Marketplace, Harper Collins Publisher, New York, NY, 1994.

Ohmae Kenichi, The Myths and Realities of Japanese Corporation, Japan Society Gallery, Japan, 1992.

Ohmae Kenichi, Managing in a Borderless World, Harvard Business Review, 1990, pp. 151-161.

Ohmae Kenichi, The Mind of the Strategist. Business Planning for Competitive Advantage, Penguin Business Library, 2nd Edition, 1986.

Ohmae Kenichi, The Mind of the Strategy: The Art of Japanese Business, McGraw-Hill, 1 edition, New York, NY, 1982.

Ohno Taiichi and Mito, S., Just-In-Time for Today and Tomorrow, Productivity Press, Portland, OR, 1988.

Ohno Taiichi, Toyota Production System: Beyond Large Scale Production, Productivity Press, Portland, OR, 1988.

Ohno Taiichi, Workplace Management, Productivity Press, Portland, OR, 1988.

Salvioni Daniela M., Market-Driven Management and Corporate Governance, Symphonya. Emerging Issues in Management (symphonya.unimib.it), n. 2, 2008 http://dx.doi.org/10.4468/2008.2.02salvioni

Salvioni Daniela M., Corporate Governance, Management Control and Global Competition, Symphonya. Emerging Issues in Management (symphonya.unimib.it), n. 1, 2005. http://dx.doi.org/10.4468/2005.1.03salvioni 
Salvioni Daniela M., Corporate Governance and Global Responsibility, Symphonya. Emerging Issues in Management (symphonya.unimib.it), n. 1, 2003.

http://dx.doi.org/10.4468/2003.1.05salvioni

Schuiling Isabelle, Successful Market-Driven Organization, Symphonya. Emerging Issues in Management (symphonya.unimib.it), n. 2, 2000/2001. http://dx.doi.org/10.4468/2001.2.06schuiling

Sciarelli Mauro, Resource-Based Theory and Market-Driven Management, Symphonya. Emerging Issues in Management (symphonya.unimib.it), n. 2, 2008.

http://dx.doi.org/10.4468/2008.2.06sciarelli

Shapiro Benson P., What the Hell is Marketing Oriented, Harvard Business Review, 66(6), 1998.

Slater Stanley F., Narver John C.,Market Orientation, Customer Value, and Superior Performance, Business Horizons, March-April, 1994.

http://dx.doi.org/10.1016/0007-6813(94)90029-9

Slater Stanley F., Narver John C., Customer-Led and Market-Oriented: Let's Not Confuse the Two, Strategic Management Journal, vol. 19, n. 1, 1998.

http://dx.doi.org/10.1002/(SICI)1097-0266(199810)19:10<1001::AID-SMJ996>3.0.CO;2-4

Slater Stanley F., Narver John C., Market-Oriented Is More that Being Customer-Led, Strategic Management Journal, vol. 20, n. 12, 1999. http://dx.doi.org/10.1002/(SICI)1097-0266(199912)20:12<1165::AID-SMJ73>3.3.CO;2-R

Sloan Jr. Alfred P., My Years with General Motors, Doubleday, Bantam Doubleday Dell Publishing Group Inc, New York, NY, 1990.

Taylor Frederick W., The Principles of Scientific Management, Harper \& Brothers, New York, NY, and London, UK 1911.

Vallini Carlo, Simoni Christian, Market-Driven Management as Entrepreneurial Approach, Symphonya. Emerging Issues in Management (symphonya.unimib.it), n. 1, 2009.

http://dx.doi.org/10.4468/2009.1.03vallini.simoni

Webster Jr. Frederick E., Market-Driven Management, John Wiley and Sons, Hobboken, 1994.

Webster Jr. Frederick E., Marketing-Driven Management. How to Define, Develop and Deliver Customer Value, Second Edition, John Wiley \& Sons, New York, 2002.

Webster Jr. Frederick E., The Changing Role of Marketing in the Corporation, Journal of Marketing, 56, October 1-17, 1992.

http://dx.doi.org/10.2307/1251983

Webster Jr. Frederick E., The Future Role of Marketing in the Organization, in Lehman D.R. E Jocz K.E. (ed.), Reflections on the Futures of Marketing, Marketing Science Institute, Cambridge, MA, 1997.

Webster Jr. Frederick E., The Rediscovery of the Marketing Concept, Business Horizons, vol. 31, May-June 1988.

http://dx.doi.org/10.1016/0007-6813(88)90006-7

Zucchella Antonella, Majocchi Alberto, Global Entrepreneurship and Market-Driven Management, Symphonya. Emerging Issues in Management (symphonya.unimib.it), n. 2, 2008.

http://dx.doi.org/10.4468/2008.2.04majocchi.zucchella

\footnotetext{
Notes

${ }^{1}$ The assembly line made it possible to increase the number of cars produced in a single unit of time compared to manufacturers that were still anchored to artisan methods, and therefore to lower the unit cost and thus the selling price, making the purchase accessible to vast areas of the population.

${ }^{2}$ However, it is clear that a correct stocks policy must be implemented upstream, in other words at the purchasing end to avoid interrupting the manufacturing process, and this usually translates into a very rigid manufacturing organisation, which can bring significant economies of scale and of experience.

${ }^{3}$ The need to launch a new product comes from the market, and is 'pulled' by the market itself.

${ }^{4}$ For example, a function that was previously performed by several people in different functions is now performed by a single person with a conspicuous reduction in costs and a significant saving in the time necessary to transfer, analyse and coordinate information flows.
} 